\title{
Chapter 13 \\ Network Analysis to Model and Analyse \\ Roman Transport and Mobility
}

\author{
Pau de Soto
}

\begin{abstract}
The analysis of Roman infrastructures, which helps to understand the transport costs, the commercial routes and the territorial configuration, is an indispensable way to know the benefits and shortcomings of the transportation system created in Roman times. It is well known that the Roman Empire built the first big transport network in Western Europe, parts of Eastern Europe, the Middle East and Northern Africa. In this paper, we show our attempt to reconstruct the Roman transport conditions in Hispania by valuating its connectivity and by modelling the travel costs and times. All of these calculations have been made based in a highly digitized transport network and Network Science applications. The results of such methodologies provide us with new information to understand the Iberian territorial organisation, the distribution of commodities, product competition and problems of stagnation in ancient economies such as that of Ancient Rome.
\end{abstract}

Keywords Roman transport · Roman commerce $\cdot$ Network analysis · Archaeology - Trade

\subsection{Introduction}

Analysing and understanding the distribution systems of goods in antiquity has not been (nor is it) a simple task. There are many elements that must be taken into account such as infrastructures, means of transport, goods, geological conditions and so on. Traditionally, scholars have used different material testimonies (amphorae, ceramics, marbles, etc.) or written sources to interpret the movement of goods. Until now, scholars have made different methodological approaches to define the

\footnotetext{
This project has received funding from the European Union's Horizon 2020 research and innovation programme under the Marie Skłodowska Curie grant agreement No 706260

P. de Soto $(\bowtie)$

Instituto de História Contemporânea, Faculdade de Ciências Sociais e Humanas, Universidade Nova de Lisboa, Lisbon, Portugal
} 
performance of historical transport networks. The study of Ancient sources and archaeological materials and their dissemination have been used as a proof of commerce and as a main element to determine the existence and morphology of transport routes. But, both kinds of sources uniquely give testimony of the relationship between places (mostly origin and destination of goods), and we still miss a lot of information about the possible routes and the economic impact of them. For that reason, recently there has been a growing interest in creating new ways of quantifying the historical economy and trade (Adams 2007; Bowman and Wilson 2009; De Callataÿ 2014; Meijer and Van Nijf 1992).

The communication and transport infrastructures of each historical period were built and maintained based on their multiple functions within each territory. Roads enabled the export of the goods produced as well as the import of the products that were needed. For this reason, the geographical situation of each urban settlement greatly conditioned their economic possibilities, while the construction of certain infrastructures could sensibly give rise to the alleviation of certain adversities. This issue was highlighted for example by Pliny the Younger in his letter addressed to the emperor Augustus (Ep. X, 46):

Bordering upon the territories of the city of Nicomedia is a most extensive lake; over which marbles, fruits, woods, and all kinds of materials, the commodities of the country, are brought over in boats up to the highroad, at little trouble and expense, but from thence are conveyed in carriages to the seaside, at a much greater charge and with great labour. ${ }^{1}$

Moreover, the construction of new infrastructures, especially in Roman times, clearly served as a propaganda showing the benefits of the Roman domination of the territories. Each great road was marked with milestones providing information to the travellers about which emperor had defrayed the costs of its construction or remodelling. Likewise, triumphal arches, bridges or ports would serve the same purpose. In addition, the improvement in the communications (thanks to the construction of roads that allowed a faster and safer circulation) favoured the connections between territories and the circulation of news and political orders. The construction of these roads also allowed the movement of people, an indispensable element for the dissemination of ideas and religious currents. A paradigmatic case was, for example, the expansion of Mithraism from the East, which was mainly exported by Roman soldiers in places as far away as Rome, Mauritania, Hispania or Britannia.

The development of new technologies, such as GIS, or the application of new methodologies in archaeology such as Network Analysis has allowed us to go a step further and try to model trade and transport in ancient times in different ways.

The Mercator-e project, financed by an IF Marie Curie grant (Project 706260MSCA | H2020), is focused on the comparative analysis of transport infrastructures in the Iberian Peninsula over a long period of time which is from the Roman times

\footnotetext{
${ }^{1}$ Pliny the Younger (1909-1914/2001). Letters. Translated by W Melmoth, revised by FCT Bosanquet. P.F. Collier \& Son/Bartleby.com, New York. Available at http://www.bartleby.com/9/4/. Accessed on 15 December 2017.
} 
until the mid-nineteenth century. ${ }^{2}$ The chosen territory stands out for representing an almost closed geography, which allows to carry out studies in itself.

The studies carried out are focused on the analysis of the morphology of Roman transport networks, that is, how the territory was configured and ordered from the construction of infrastructures (more connected areas vs. more isolated areas). In addition, a study on the functionality of these transport networks has also been developed to complete the knowledge on transport. This second study is based on the calculation of transport costs and times.

\subsection{The Iberian Transport Networks}

The Iberian Peninsula is an enormously diverse geographical environment where large and wide plains, fertile river valleys, long maritime coasts and rugged mountain systems are combined. The adaptation of a territorial organization to this large and diverse territory, whose main architect is considered to be Agrippa (Rodà 1998), required a great effort of design. The progressive conquest of the Iberian territories by Rome, in a process that lasted around two centuries (218 BCE-219 BCE), caused the existence of a complex communication network, which combined military, political, social and economic motivations.

The construction of the communication system in Hispania must be understood, therefore, from the perspective of the military evolution that took place in these territories, with the subsequent adaptations that were carried out to economically exploit the most fertile areas. There are different kinds of sources that allow us to reconstruct the Iberian land road networks. Classical authors like Titus Livius, Strabo or Julius Caesar, ancient sources like the Antonine Itinerary, the Vicarello Cups or the Tabula Peutingeriana and archaeological features like milestones and road fragments, allowed the researchers to establish the paths of these tracks (Carreras and De Soto 2010, 19-24). The North-East of the Iberian Peninsula was the epicentre of Roman communications during the arrival of Rome and maintained its main role during all the following centuries. The capital of the Hispania Citerior province (called later Hispania Tarraconensis) was established in Tarraco. The territories of the NE were the closest to Rome (both by sea and by land) of the entire Iberian Peninsula. This gave them a consideration as that of a gateway to the entire province.

Across the Eastern Pyrenees, the continuation in Hispania of the Gaul's road known as Via Domitia took the name of Via Augusta. This route crossed the entire Mediterranean coast to go towards the south of the Iberian Peninsula, passing through Hispalis and reaching Gades. There was also an important deviation from

\footnotetext{
${ }^{2}$ The objective of the Mercator-e project (http://fabricadesites.fcsh.unl.pt/mercator-e) is to analyse the evolution of transport networks from the Roman Era to the nineteenth Century. Consequently, it is also possible to visualise the medieval communications and the seventeenth and nineteenth century transport networks, in addition to the Roman roads.
} 
Tarraco that was directed towards the Northwest. This horizontal axis (E-O), which linked together the two sides of the Iberian Peninsula, has historically been configured as a very important communication axis. During the conquest of Hispania, this axis was required to supply the Roman armies in the different military campaigns of the north (Numantia, Cantabrian Wars), and it was a hub of communications with the rich gold mines (Las Médulas). Some centuries later, in the medieval ages, the importance of this axis survived being fossilized as the well-known Camino de Santiago.

Other important roads were built in the Roman era in the peninsula such as the axis which, from Caesaraugusta, headed towards Emerita Augusta crossing the whole peninsula from the Northeast to the Southwest. Finally, it is important to highlight two other axes that linked the north and south of the Iberian Peninsula. The first one crossed the entire Atlantic façade on a route that was very close to the coast; it is known as the Via Atlantica and connected cities such as Osonoba on the south coast with Olisipo, Conimbriga and Bracara Augusta reaching Brigantium. Following the same direction, there was another route that headed towards Emerita Augusta, in order to go to the North, from Hispalis to the Cantabrian area passing through Salmantica and arriving at Asturica Augusta.

But the Roman transport system in the Iberian Peninsula was not only based on the construction of road infrastructures. Romans took advantage of the benefits offered by the different waterways. The Iberian Peninsula has an important group of rivers and lagoons that drain into three different drainage basins.

The rivers of each of these drainage basins are very different and offered very diverse transportation options. Due to the proximity to the Cantabrian mountain range, the rivers of this basin and its courses are very numerous of abundant waters, short and pronounced. These rivers offered few possibilities of transport use in Roman times. The rivers of the Atlantic basin are very extensive, some born near the Mediterranean, but due to the inclination of the Meseta they end up flowing into the Atlantic Ocean. Due to the climatology, they are irregular, especially in summer. But the numerous tributaries allowed a deep inland navigation in Roman times. Finally, the rivers of the Mediterranean basin stand out for being short and very seasonal, completely disappearing in dry summers. The exception in this aspect is the Ebro River, the largest river in the Iberian Peninsula. The Ebro River was used as a transport route from the Roman era to the Modern Age. Classical authors like Pliny or Strabo offered information about the navigability of some of the Iberian rivers (Parodi 2001; Carreras and De Soto 2010).

Last, but not least, we defined the maritime transport network. The use of the sea for commercial purposes in Roman times was very important as has been demonstrated by the ancient sources, the artistic representations and the numerous discovered wrecks. In the Iberian Peninsula, various cities benefited from the construction of port infrastructures like Tarraco, Dertosa, Valentia, Carthago Nova, Hispalis, Olisipo and many others were connected with Rome and with many other cities thanks to the circulation of large ships. In the north of the peninsula, several lighthouses helped navigation to avoid accidents in the dangerous waters of the Cantabrian Sea. Thanks to the archaeological information, it is possible to establish the sea connectivity of the Iberian coastal cities in conjunction with references in ancient sources. 


\subsubsection{Digitization of Transport Networks}

In previous projects, it was possible to apply the methodological concepts and analysis to a transport network that included the main and secondary roads of the Iberian Peninsula (Carreras and De Soto 2010, 2013; De Soto 2010b, 2011, 2013). However, the current project intends to go a step further using a highly detailed digitized transport network as a base. Thus, from the beginning of Mercator-e, the digitization of all the roads was planned with as much detail as possible. To achieve this goal, the most detailed archaeological published studies were used as well as contacts made with the road researchers to obtain permission to use their digitized data. Diverse recent works have been published on transport networks in Roman Hispania (De Soto 2010a; Moreno 2011; Argüelles Álvarez 2015; Almeida 2017; Fonte et al. 2017). Among them, some used for their projects Geographical Information Systems, so thanks to their willingness to share their data, it was finally possible to include their data into the project database. For the rest of the information, both the published maps and the information and descriptions provided in their texts were counted and digitized. Thanks to this collaboration, the Mercator-e Project is becoming a great open repository, where we can find all the information about historical transport networks of the Iberian Peninsula. ${ }^{3}$

The result of this digitization work has been enormous (Fig. 13.1) if we take into account the size of the geography of the Iberian Peninsula and the number of Roman roads. The means of communication have been catalogued in four different categories depending on the means of transport they represent and their category. Thus, we can find maritime routes, waterways and main and secondary roads. In total, $41,781 \mathrm{~km}$ of terrestrial communication roads were digitized, $2868 \mathrm{~km}$ of navigable rivers and $4759 \mathrm{~km}$ of maritime connections. All this network of Roman infrastructures digitized with high detail represents the largest compilation of routes and routes of the Iberian Peninsula carried out until today. ${ }^{4}$ Nowadays, it is possible to visualise all the digitized networks with high precision in the project webpage (http://fabricadesites.fcsh.unl.pt/mercator-e/), but following the Horizons 2020 Open Data policy, it is also possible to observe the Mercator-e's Roman Networks in other Linked Open Data online platforms related to antiquity as the Digital Atlas of the Roman Empire from the Pelagios Commons project (http://dare.ht.lu.se/). In order to create a more dynamic project, all the Mercator-e's networks will be openly accessible to downloads in the near future to let scholars use them in their own projects.

The base used to digitize the different routes has depended on the digital data available in each country. Consequently, in Spain, it has been possible to use the municipal topographic base (1:5000), whereas in Portugal, the database used has been noticeably less detailed, but it has been compensated with the digitization of

\footnotetext{
${ }^{3}$ Up to now, eight different projects and researchers have shared their digitized data with the Mercator-e Project. At the same time, five research projects have been interested in using the Mercator-e networks.

${ }^{4}$ Until now, the most important collection on the Roman roads in the Iberian Peninsula has been made by Arias (2004), compiling all the data collected between the years 1963-2006.
} 


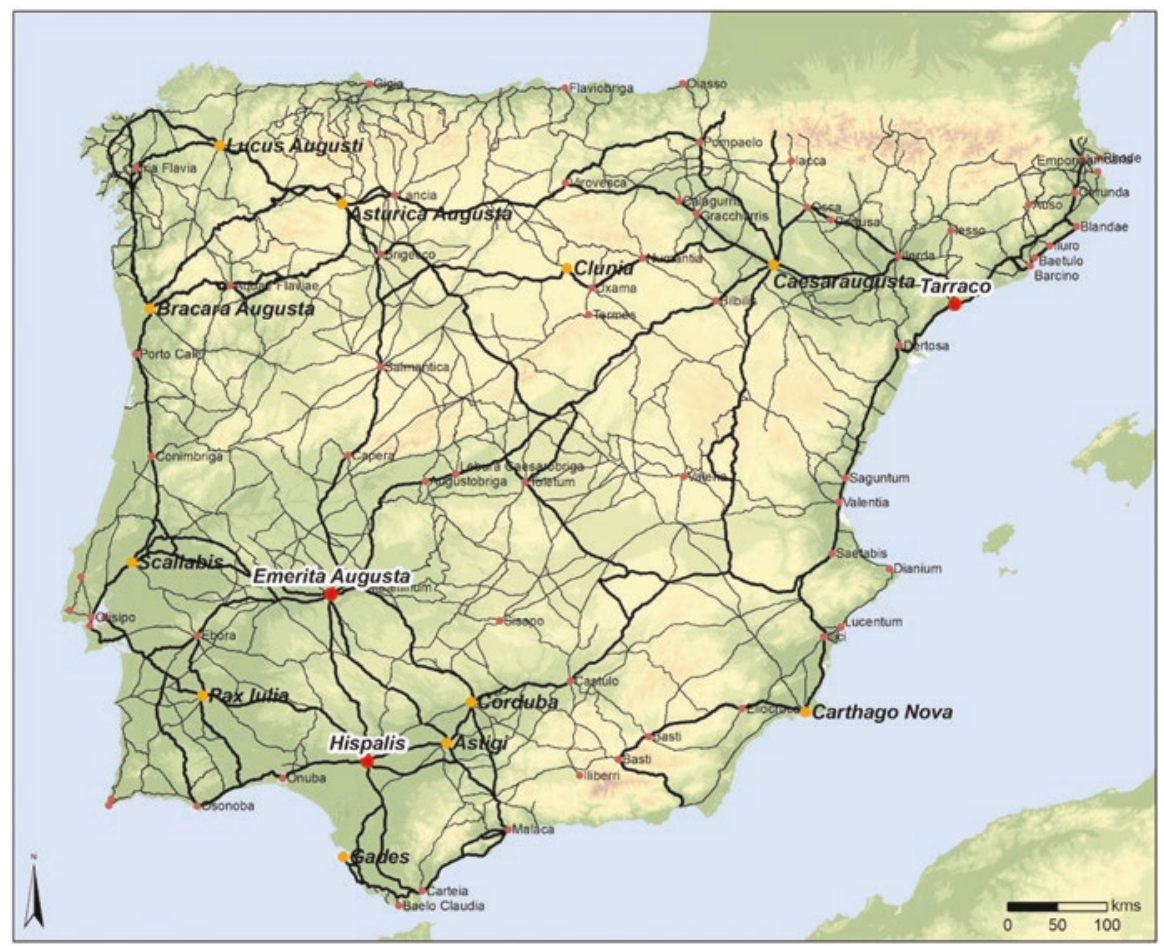

Fig. 13.1 Map of Roman roads digitised in the Mercator-e project

different topographic maps a little bit older, which are from the early twentieth century. Because the objectives of the Mercator-e project include the diachronic study of the Iberian Peninsula, it has also been possible to compare the routes of the Roman roads with the medieval, modern and contemporary routes.

\subsection{Methodology}

\subsubsection{Network Analysis Applied to Historical Transport Roads}

The use of Network Analysis is currently widespread throughout our society. From genealogical trees or subway maps to many other applications such as social networks or online road maps, they use some of the concepts developed in Network Analysis in one way or another. The conceptual basis of Network Analysis is the Graph Theory. This theory, widely used today, has its origin in the eighteenth century. In 1736, Leonhard Euler, a renowned mathematician confronted a problem, raised by the city of Königsberg, about the possibility of crossing its seven bridges without repeating any. Despite the fact that Euler found it impossible to solve that 
problem, his procedures to find a solution was a key factor for the Graph Theory's future. He converted each land area into a node (point) and each bridge into an edge (line). The ability to translate a real (or imaginary) concept into a scheme formed by points and lines became the base of Graph Theory. Since 1736, many other researchers from many different science fields have used this methodology: in 1847 Kirchhoff in order to work on electrical systems, in 1857 Cayley and the isomers of an organic compound, in 1859 Hamilton devised some journeys in dodecahedrons or Jordan and in 1869 studied abstract tree forms among others.

In the Mercator-e project, the Graph Theory is applied to the analysis of transport infrastructures. The basis of the project is to identify cities and urban settlements as nodes while the road sections that connect them are identified as edges. This methodology is not new and has been applied before in various archaeological studies on transport and archaeology (Graham 2006; De Soto and Carreras 2008; Isaksen 2008; Brughmans 2013; Preiser-Kapeller and Werther 2016). The conversion of real historical transports into structures formed by graphs offers a large number of options to perform calculations and interpret the roles of the different urban centres, in this case within the Roman transport network in the Iberian Peninsula.

\subsubsection{Connectivity}

Thanks to the evolution in Social Network Analysis studies, there are different methods and calculations to evaluate the position and role of the different nodes within a network. Freeman (1979) already clarified the mathematical principles of some of these calculations such as centrality, closeness and betweenness degree for use in social sciences. Much has been written about its application in other disciplines, including archaeology (Mills 2017). In recent decades, its use in archaeology has increased exponentially (Brughmans 2010, Collar et al. 2015), allowing us to analyse very diverse elements and relationships in this field.

The centrality calculations allow scholars and researchers to analyse on key elements of the configuration and integration of territories. Historical connectivity of the Mediterranean has been fully developed with wide acceptation in the work of Horden and Purcell (2000) although with some criticism about its quantification models or the difficulty to explain the evolution of the connectivity during the different Roman highly urbanised phases (Tacoma and Lo Cascio 2016, 14). In this project, we understand the connectivity as the capacity of the different urban settlements to allow the circulation of people and goods. This connectivity could also be understood as accessibility. The basis for this analysis is the belief that in historical times there was a direct relationship between the quality and quantity of infrastructures and the economic, political and social significance of each settlement. Important cities and provincial capitals benefited from the construction of important transport routes, large roads, fluvial and/or maritime ports that allowed them to nourish with all the goods they needed, as well as facilitated the arrival and departure of citizens. In this way, a simple and direct methodology of visualizing the significance of an establishment through the quantification of its accessibility has been configured. 
Table 13.1 Centrality values of each edge type

\begin{tabular}{l|l|l|l|l}
\hline Means of transport & Capacity & Speed & Cost & Edge Value \\
\hline Sea transport & $92 \mathrm{~T}$ & $4.25 \mathrm{~km} / \mathrm{h}$ & $0.097 \mathrm{~kg}$ wheat T/km & 4 \\
\hline River transport & $5,5 \mathrm{~T}$ & $2.51-0.62 \mathrm{~km} / \mathrm{h}$ & $0.33-0.66 \mathrm{~kg} \mathrm{w} . \mathrm{T} / \mathrm{km}$ & 3 \\
\hline Land (main road) & $0.4 \mathrm{~T}$ & $2.1 \mathrm{~km} / \mathrm{h}$ & $4.92 \mathrm{~kg}$ wheat T/km & 2 \\
\hline Land (secondary road) & $0.1 \mathrm{~T}$ & $3 \mathrm{~km} / \mathrm{h}$ & $4.92 \mathrm{~kg}$ wheat T/km & 1 \\
\hline
\end{tabular}

Adapted from De Soto 2010a

The Mercator-e project is based on a methodology that has been developing in recent years to quantify accessibility from transport infrastructures (De Soto and Carreras 2008; De Soto 2011; Carreras and De Soto 2012). The calculation of the centrality degree is used as a methodological basis, that is, the value of each node corresponds to the sum of the total number of edges that are connected to it. The main methodological novelty of this calculation lies in the different weights given to each edge in relation to the means of transport that they represent, creating a weighted network (Barrat et al. 2004). According to this method, the edges of a network are tested not only if they are absent or not (binary calculation), but they can have different values and, therefore, the weight of a node is calculated from the sum of the different values of the edges that are communicated. For non-social networks, the weight often represents the capacities of the ties, for example, the airports' connections (e.g., the number of seats among airports, Colizza et al. 2007, Opsahl et al. 2008). In this way, the weight of the edges depends on the importance of the road that they represent and the characteristics of the means of communication used. For this project, four different types of edges have been catalogued depending on whether they represented a maritime communication, a fluvial communication, a main road or a secondary road.

As can be seen in the previous table (Table 13.1), the edges that represent maritime communications are given the highest value (4). This is due to the importance of maritime transport in antiquity, which allowed the distribution of large quantities of goods at the highest speeds compared with other means of transport. Therefore, as the classical sources have reflected, the availability of a port was very appreciated by its inhabitants. A clear example of this can be shown through the words of Gregory Nazianzes (Orationes 43):

For maritime cities are able to bear such times of need without difficulty, by an exchange of their own products for what is imported: but an inland city like ours can neither turn its superfluity to profit, nor supply its need, by either disposing of what we have, or importing what we have not... ${ }^{5}$

In the next place, the edges that offer a higher value of centrality, but less than those representing the maritime connections, are those that represent a fluvial transport. The cities that were built in the vicinity of a navigable river were also favoured by

\footnotetext{
${ }^{5}$ Gregory Nazianzes (1894) Orations. Translated by CG Browne and JE Swallow. In: Schaff P, Wace H (eds) Nicene and Post-Nicene Fathers, Second Series, Vol. 7. Christian Literature Publishing Co., Buffalo (NY). Revised and edited by K Knight. Available at http://www.newadvent.org/fathers/310243.htm. Accessed on 12 May 2018.
} 
the possibilities which these fluvial courses offered for the transport of merchandises. Although much more limited than shipping, river transport had good transport characteristics downstream, while it has much less favourable condition in the opposite direction (upstream).

Finally, the last two categories of edges correspond to means of land transport. The differentiation between both types of edges is based not on the characteristics of the means of communication that circulated through them but on the category of the roads. As discussed in Sect. 13.2, on the one hand, it has been considered opportune to identify the routes depending on their role in the communications of the territories, as main roads have been considered those that were collected in itineraries and ancient sources due to their importance. Some examples in the Iberian Peninsula could be the Via Augusta or the Via Atlantica. And at the same time, those roads with archaeological data without having the same importance as the main roads have also been collected as secondary roads. These roads have been considered secondary, due to their morphology and their position within the transport network.

As a result of the application of this methodology to value the different types of edges, we have obtained a weighted Network where a node with few connections has a higher value than other nodes with a greater number of edges, because the final centralidy degree will depend on the value of the edges. It could be interpreted that the final value of the centrality in this project is not only a quantitative value but also a qualitative one (Fig. 13.2).
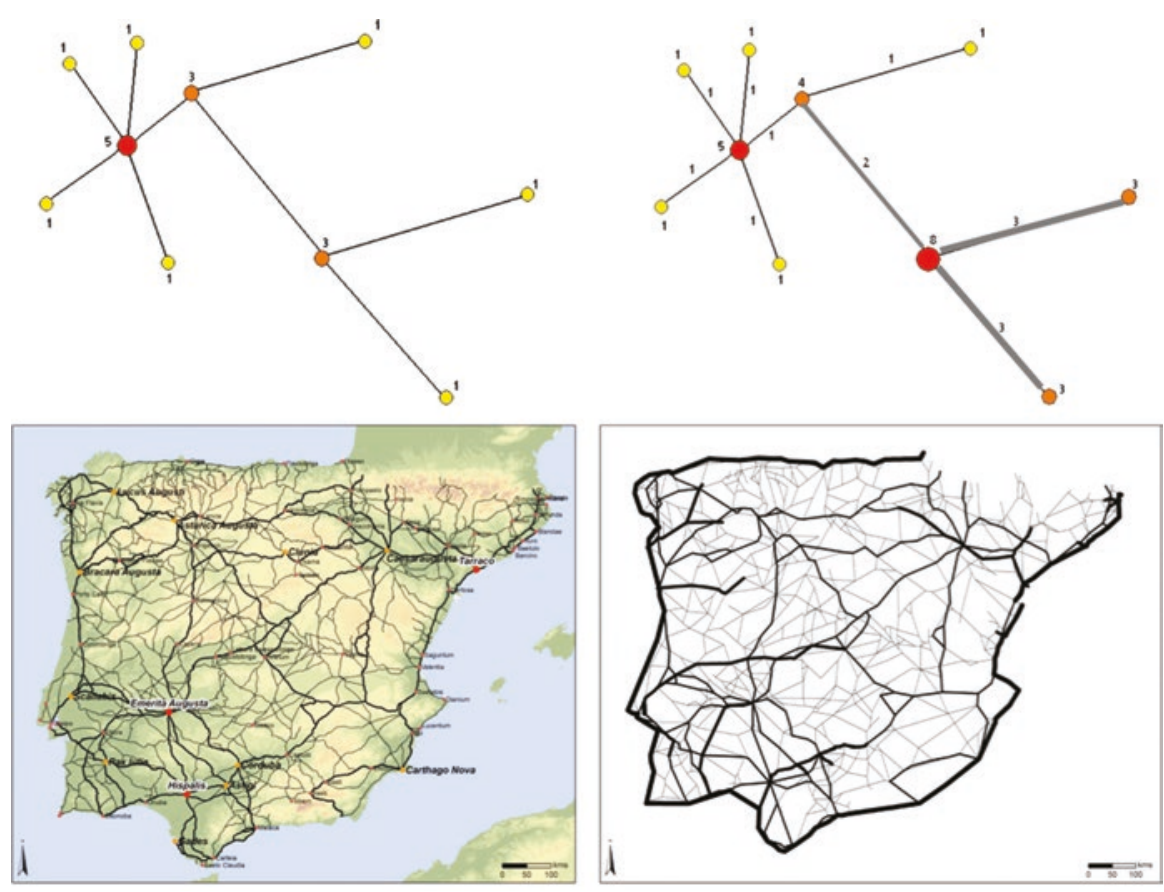

Fig. 13.2 Scheme on the change of the value system of the edges (above) and the result of its application in the Roman transport network in the Iberian Peninsula (below) 


\subsubsection{Transport Time Costs and Financial Expenses}

Another element analysed in this project focuses on the analysis of the functionality offered by the Roman transport network. This aspect evaluates the situation of each territory of the Iberian Peninsula in relation to the transport costs (in money and time) that is needed to transport goods to the rest of the network. The data generated creates a clear visualization of the position of the different cities and territories to favour an active commercial economy.

It is important to remark that these calculations do not attempt to determine the exact cost of transporting a commodity in a given path but rather to establish dispersion or distribution models in relation to estimated costs. Today, with the data and knowledge available, it is still very difficult to try to establish an exact cost for the transport of merchandises in the Roman period. In fact, the only accurate information that has survived has been from some small references of costs in written sources and some legal price lists.

The functionalities offered by Geographic Information Systems and Network Analysis have been used to computerize and simulate the theoretical time cost and financial expense of transport through Iberian transport networks in the Roman period. The methodological basis for carrying out these calculations is based on the use of cost and speed transport values per kilometre travelled that are applied to previously digitized transport networks in a GIS environment. In this way, the more detailed the digitized network is, the more detailed and precise the results obtained can be.

For this reason, due to the search for the most approximate results and possible de-carvings, the digitization of the networks of the different means of transport has been digitized with the greatest possible detail. Thus, all the terrestrial roads respect the geographical features and the different characteristics of the orography through which they pass.

One of the most transcendental elements of this project has been the establishment of the values for the calculation of transport costs and times. So far, data obtained in previous projects have been used (De Soto 2010a; Carreras and De Soto 2010). To perform the calculations on the functionality of the transport network, two different types of values are distinguished. On the one hand, the time needed to distribute goods from one point to the rest of the network is evaluated. For this purpose, it has been necessary to determine the average speeds for each different means of transport. The analysed data have been extracted from different classical sources as well as from ethnographic data.

Maritime transport was the fastest means of transport in Roman times. The large vessels that crossed the Mediterranean as well as boats of smaller dimensions took advantage of the currents and the winds to travel long distances in reduced times. Pliny the Elder (NH XIX, 3-4) perfectly describes the Roman view of maritime circulation:

... and in what production of the earth are there greater marvels revealed to us than in this?

To think that here is a plant which brings Egypt in close proximity to Italy!-so much so, in 
fact, that Galerius and Balbillus, both of them prefects of Egypt, made the passage to Alexandria from the Straits of Sicily, the one in six days, the other in five! It was only this very last summer, that Valerius Marianus, a senator of protorian rank, reached Alexandria from Puteoli in eight days, and that, too, with a very moderate breeze all the time! To think that here is a plant which brings Gades, situate near the Pillars of Hercules, within six days of Ostia, Nearer Spain within three, the province of Gallia Narbonensis within two, and Africa within one! - this last passage having been made by C. Flavius, when legatus of Vibius Crispus, the proconsul, and that, too, with but little or no wind to favour his passage! ${ }^{6}$

The main propulsion of these boats were the sails, supported with oars in their approaches to the ports and complicated zones. The speeds of the Roman ships have already been studied before, with Lionel Casson being one of its most important researchers. According to this author (Casson 1985), after collecting some classic sources, he determined that there were two different speeds: 6.75 knots in favourable conditions and 3 knots in unfavourable wind conditions ( $16 \mathrm{~h}$ of navigation per day). More recently, other authors have analysed this question again (Arnaud 2005; Lawton 2004; Scheidel 2013), modifying and incorporating some data. Cabotage navigation, the most used to redistribute goods from the large ports that connected different provinces to the rest of the maritime settlements of the transport network, had limited the speeds because the proximity of the coast reduced the existence of winds and the navigable conditions (McGrail 1983). With all the data provided, an average speed (favourable/unfavourable winds) was established for maritime transport of $2.3 \mathrm{knots}(4.26 \mathrm{~km} / \mathrm{h})$.

In Roman times, other much used means of communication were the different waterways. In certain territories, the rivers represented true arteries of penetration inside the territories. In the case of the Iberian Peninsula, it is well known that the main rivers were used as transport paths. Fluvial ports are known, and data have been preserved in written sources about the use of Iberian rivers as means of transport (Parodi 2001). But determining the speeds of river boats in Roman times has been a difficult task, mainly due to the lack of data on these fluvial media in the written sources. In river navigation, two situations are clearly distinguished and differentiated: downstream and upstream navigation. The first represented the simplest form of transportation. It required very little crew, and depended on the speed of the river waters. In the second case, for the upstream navigation, the help of human or animal traction from the shore was necessary to overcome the unevenness. It was also necessary to build certain infrastructures on the banks such as towpaths. Pliny the Elder (NH VI, 102) documented a trip across the Nile River upstream between the Delta and Coptos that lasted 12 days, although the case of the Nile is not exactly comparable to the rivers of the Iberian Peninsula. These data together with other ethnographic information (Carreras 1994; Carreras and De Soto 2010) allowed to establish a speed of $2.51 \mathrm{~km} / \mathrm{h}$ for the transport of merchandise by river downstream, while a speed of $0.62 \mathrm{~km} / \mathrm{h}$ has been established for the upstream transport. In order to improve the final calculations on river speeds, other recent bibliographical sources will be taken into account (Cooper 2014; Malmberg 2015).

${ }^{6}$ Pliny the Elder (1855). The Natural History. Translated by J Bostock and HT Riley. Taylor and Francis, London. Available at http://www.perseus.tufts.edu/. Accessed on 12 May 2018. 
Table 13.2 Speeds determined by this project divided by means of transport

\begin{tabular}{l|l}
\hline Means of transport & Speed \\
\hline Sea transport & $4.26 \mathrm{~km} / \mathrm{h}$ \\
\hline River transport (downstream) & $2.51 \mathrm{~km} / \mathrm{h}$ \\
\hline River transport (upstream) & $0.62 \mathrm{~km} / \mathrm{h}$ \\
\hline Land transport & $2.5 \mathrm{~km} / \mathrm{h}$ \\
\hline
\end{tabular}

Finally, the speed of land transport has also been determined. For this type of transport, we have more information. There are several authors who have reflected the transport of goods and the time needed to carry out the journeys. The average speed of a cart drawn by oxen was about 25-30 miles per day, which could mean 1.5 miles per hour $(2.1 \mathrm{~km} / \mathrm{h})$ counting rest stops (Casson 1974). Similar results were determined by Landels (1978) for the transport of carts with heavy load. These vehicles needed wide roads with little inclination. In mountainous areas, where narrower and more sinuous roads were created, caravans of pack animals were used, such as donkeys and mules. Their speeds were slightly higher, because they were easier to move. According to historical and ethnographic data, caravans of animals could travel up to 50 kilometres per day, which means a speed of $3 \mathrm{~km} / \mathrm{h}$ with a daily rest of $8 \mathrm{~h}$. For this project, a single speed for land transport has been established because if both values were used, there would always be a predilection for mountain transport (without taking into account the load capacity or the orography of the road used). For this reason, an average land transport speed of $2.5 \mathrm{~km} / \mathrm{h}$ has been established (Table 13.2).

The second aspect analysed on the performance of the transport network focuses on transport costs. As in the previous case, the methodology used to perform these calculations is based on the establishment of cost values for each means of transport. However, determining these transport costs is more complicated than knowing their speeds. In fact, very few sources have been conserved that made reference to transport costs in Roman times. For example, there are some well-known citations, such as Cato (De Agricultura 22.3), which narrates the transportation of an oil mill (circa $400 \mathrm{Kg}$ ) from Suessa to Venafro $(60 \mathrm{~km})$ in a mountainous region:

A mill is bought near Suessa for 400 sesterces and fifty pounds of oil. The cost of assembling is 60 sesterces, and the charge for transportation by oxen, with six days' wages of six men, drivers included, is 72 sesterces. The bar complete costs 72 sesterces, and there is a charge of 25 sesterces for oil; the total cost is 629 sesterces. At Pompeii one is bought complete for 384 sesterces, freight 280 sesterces. It is better to assemble and adjust on the ground, and this will cost 60 sesterces, making a total cost of 724 sesterces. ${ }^{7}$

Perhaps the most important source where transportation costs were collected from Roman times is the Edict of Diocletian, promulgated in 301 CE. (Lauffer 1971; Giacchero 1974; Roueché 1989). This legal text elaborated to establish fixed prices for certain products and economic activities offers very valuable information for

${ }^{7}$ Cato, Varro (1934). On Agriculture. Translated by WD Hooper and HB Ash. Harvard University Press, Cambridge (MA). 
Table 13.3 Transport characteristics, costs and ratios between them

\begin{tabular}{l|l|l|l|c}
\hline Means of transport & Speed & Capacity & Cost & Ratio \\
\hline Sea transport & $4.26 \mathrm{~km} / \mathrm{h}$ & $92 \mathrm{~T}$ & $0.097 \mathrm{~kg}$ wheat T/km & 1 \\
\hline River transport (downstream) & $2.51 \mathrm{~km} / \mathrm{h}$ & $5.5 \mathrm{~T}$ & $0.33 \mathrm{~kg}$ wheat $\mathrm{T} / \mathrm{km}$ & 3.4 \\
\hline River transport (upstream) & $0.62 \mathrm{~km} / \mathrm{h}$ & $0.4 \mathrm{~T}$ & $0.66 \mathrm{~kg}$ wheat $\mathrm{T} / \mathrm{km}$ & 6.8 \\
\hline Land transport & $2.5 \mathrm{~km} / \mathrm{h}$ & $0.1 \mathrm{~T}$ & $4.92 \mathrm{~kg}$ wheat $\mathrm{T} / \mathrm{km}$ & 50.72 \\
\hline
\end{tabular}

this project. Up to this point, we have used the interpretation and calculations made in previous projects (De Soto 2010a, 2010b; Carreras and De Soto 2010). The analyses carried out have established transport costs in kilograms of wheat per ton transported and kilometre travelled for each means of transport (Table 13.3):

The relationships between the costs of each means of transport are similar to other works published by other researchers like Duncan-Jones (1974): 1-4.9-56, Künow (1980): 1-5.9-62.5, Deman (1987): 1-5.8-39 or much more recently, Scheidel (2014): 1-5/10-52. In all of them, the great differences in transportation costs that would exist in Roman times, mainly between maritime transport and land transport, seem to be demonstrated.

\subsection{Results}

Up to now, the main results obtained in this project have been the creation of a new transport network of the Iberian Peninsula in Roman times. The highly detailed and as accurate as possible digitization of all communication routes (maritime, fluvial and terrestrial) has required the dedication of many efforts, as well as the preparation of a new database with all the available information. As mentioned above, 1341 sections of roads have been digitized by all means of communication that sum up to 49,408 kilometres.

The next phase of the project is to focus on the study of centrality of this new digitized transport network. Based on the results of previous projects carried out from networks that are not as complete or detailed, we have some preliminary results that allow us to advance provisional results. The expected results will allow us to interpret how the Roman transport network in the Iberian Peninsula was organized (Fig. 13.3).

From previous and less detailed projects, it could already be seen how the configuration of communications in the Iberian Peninsula responded to three main axes. On the one hand, it highlighted the route linking the northeast of the peninsula with the northwest. This great axis will be fossilized in Iberian communications on the well-known Camino de Santiago during the Middle Ages. It was an important road, connecting the oldest conquered territories with the last areas to be conquered. This must have been the route used to export the minerals and gold exploited in the northwest, with mines such as Las Médulas. This route took advantage of the facilities of passage of the Ebro valley, one of the most important productive areas 


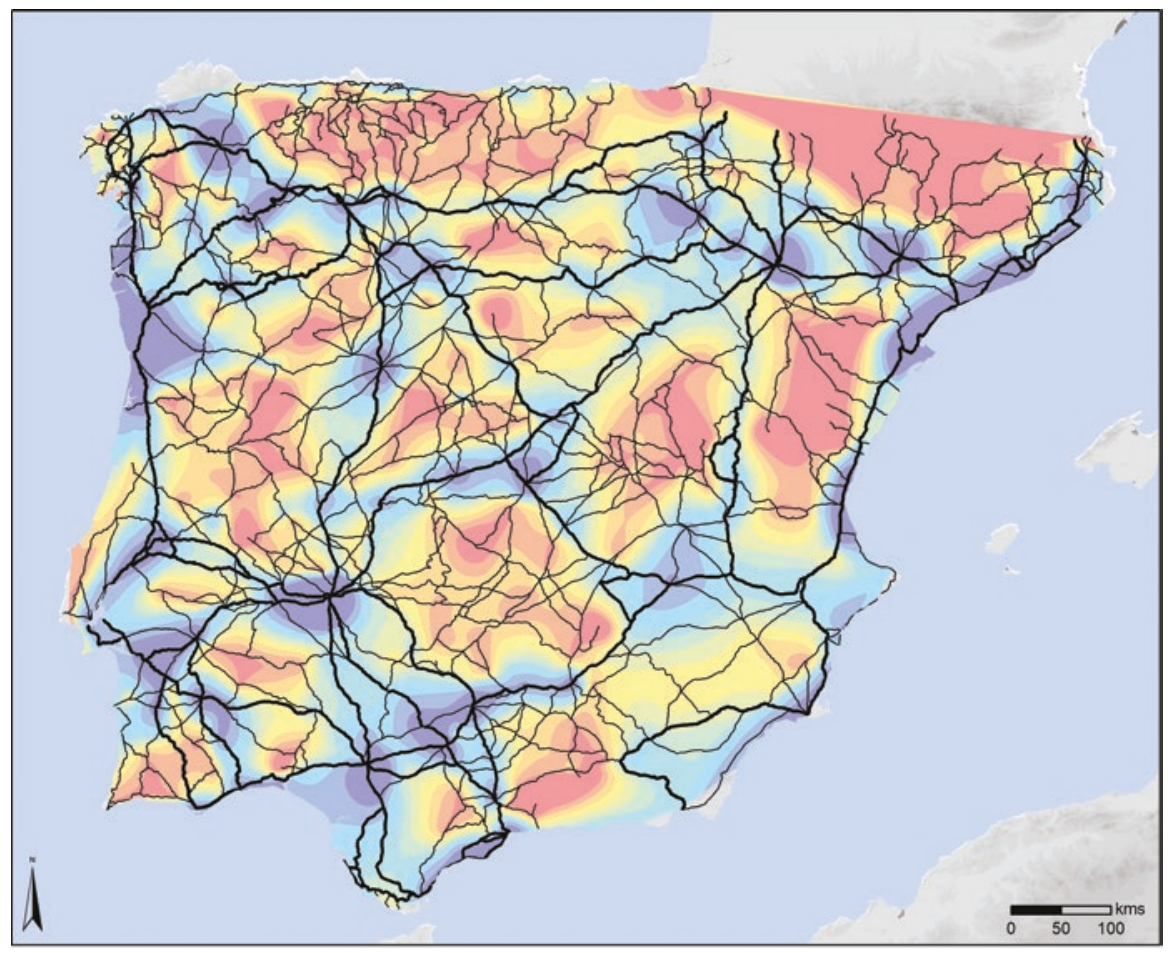

Fig. 13.3 Map of the accessibility of the Iberian Peninsula (De Soto and Carreras 2015)

of the Iberian Peninsula. Also, the whole area of the Mediterranean coast was well connected. The existence of the Via Augusta, which connected the south of the peninsula with Gaul, favoured the movement and circulation of people and goods. On this route, another river route exerted a great attraction for the development of communications, in this case the Guadalquivir River. Finally, there was another great route that communicated the south and north of Hispania. This route started from Hispalis and headed north, passing through towns such as Emerita Augusta, Salmantica or Asturica Augusta to finally reach the north-western territories of the peninsula. Conversely, large poorly communicated areas can also be seen in this first map, of which mainly were mountainous areas such as the Pyrenees, the Cantabrian Mountains, Sierra Morena or the Baetic Mountains.

As regards transportation costs, the results obtained should complement in more detail those recently obtained (De Soto and Carreras 2015) where the strong dependence of distribution on maritime and fluvial communications can be observed. Analysing the transport costs from a coastal city allows us to visualize the isolation of the inner territories of the Iberian Peninsula, and helps to explain the organization of this territory. In this case, large cities such as provincial capitals were located in easily accessible locations from the outside. All these cities were situated on the coast or in the navigable valleys of large rivers. These territories, well communicated and with reduced transport costs, were the most economically exploited territories, where more efforts were devoted to the production of oil and wine. 


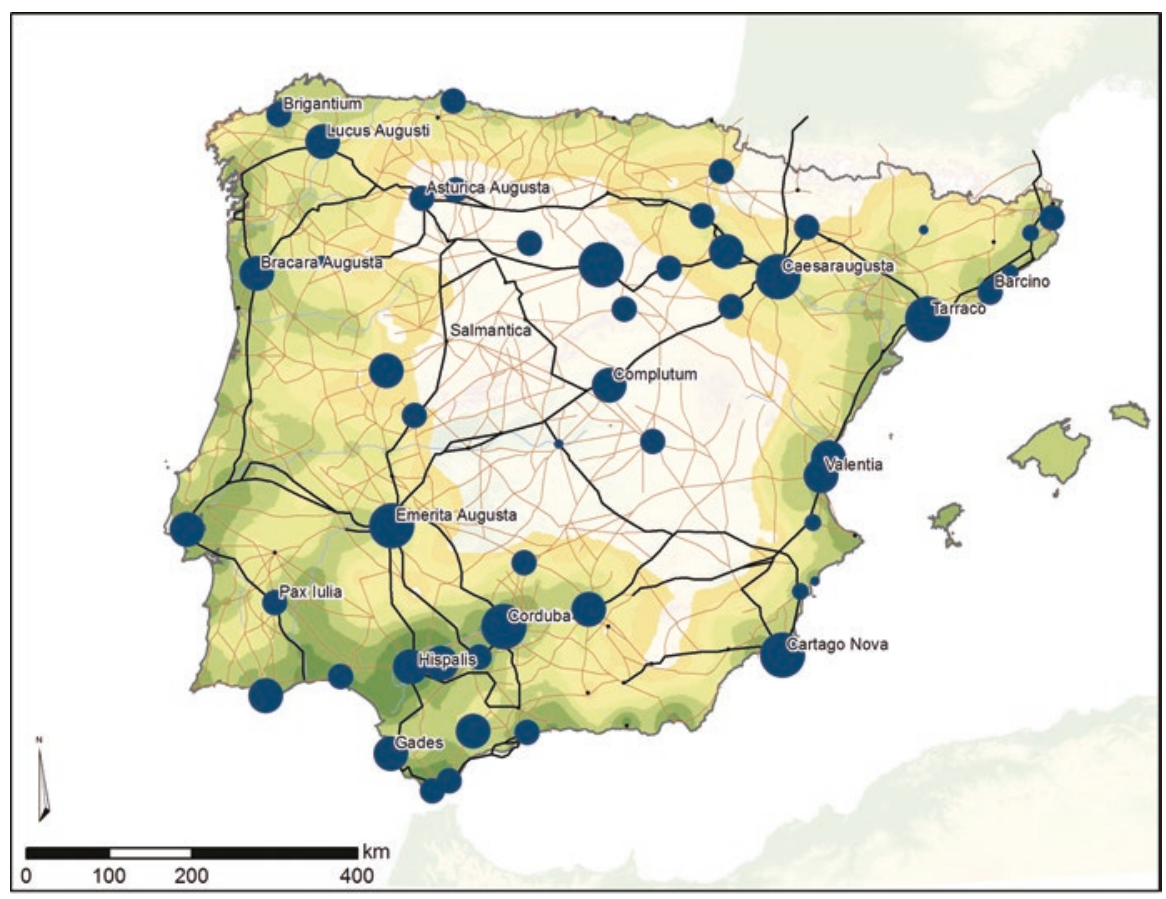

Fig. 13.4 Transportation costs from Hispalis (Seville) and measurement of the main cities of the Iberian Peninsula

From the previously obtained data, it can be seen how the most economically exploited areas were those where it was cheaper to export their goods abroad, mainly to Rome by waterways and maritime routes. These better communicated areas were the fertile valley of the Ebro River, rich in cereal production, the coastal area of the Northeast, known for its production of wine, the valley of the Guadalquivir River, famous for its enormous production of olive oil or the southwest and northwest extremes with its production of minerals and precious metals. All these areas represented the main source of wealth that Rome exploited from the Iberian Peninsula (Fig. 13.4).

\subsection{Conclusions}

The study of the configuration of transport networks allows us to visualize how a territory was organized in the past. This methodology offers quantified results on the configuration of transport routes and commercial distribution that can only be calculated with this type of analysis. Through its connectivity and transport costs, the characteristics (benefits and disadvantages) of the geographical situation of each city and territory can be understood. With this information, some economic, political and social dynamics can be explained with more quantified data. 
As an example, from the comparison between the results obtained with different types of archaeological and historical data, patterns and relationships could be established between the transport network and the political, economic or social organization of this territory. It is possible, for example, to visualize the distribution of sites destined to the exploitation of oil and wine in the Iberian Peninsula with the transport costs or the connectivity. In this case, from the results extracted from the analysis of generalized networks, it is clear how the greatest efforts of Rome served to connect the most productive areas of the Iberian Peninsula. The eastern coastal zone, the fertile valley of the Guadalquivir River or the different mining areas of the south and west of the peninsula were always perfectly communicated. In the same way, it can also be observed how the location of the largest cities responds mainly to the best connected locations. The most developed cities were located in wellconnected areas, with several means of transport and with economic facilities for the importation/exportation of products.

Definitely, the development of this project will make it possible to improve the analyses carried out to date with more precise measurements and more complete methodologies. The detail in the digitization of transport networks will offer more approximate results, taking into account aspects such as orography or a more real distance. At the same time, new analyses in centrality measurements will offer new elements to evaluate the role of different cities and territories in the construction of the transport network (Fig. 13.5).

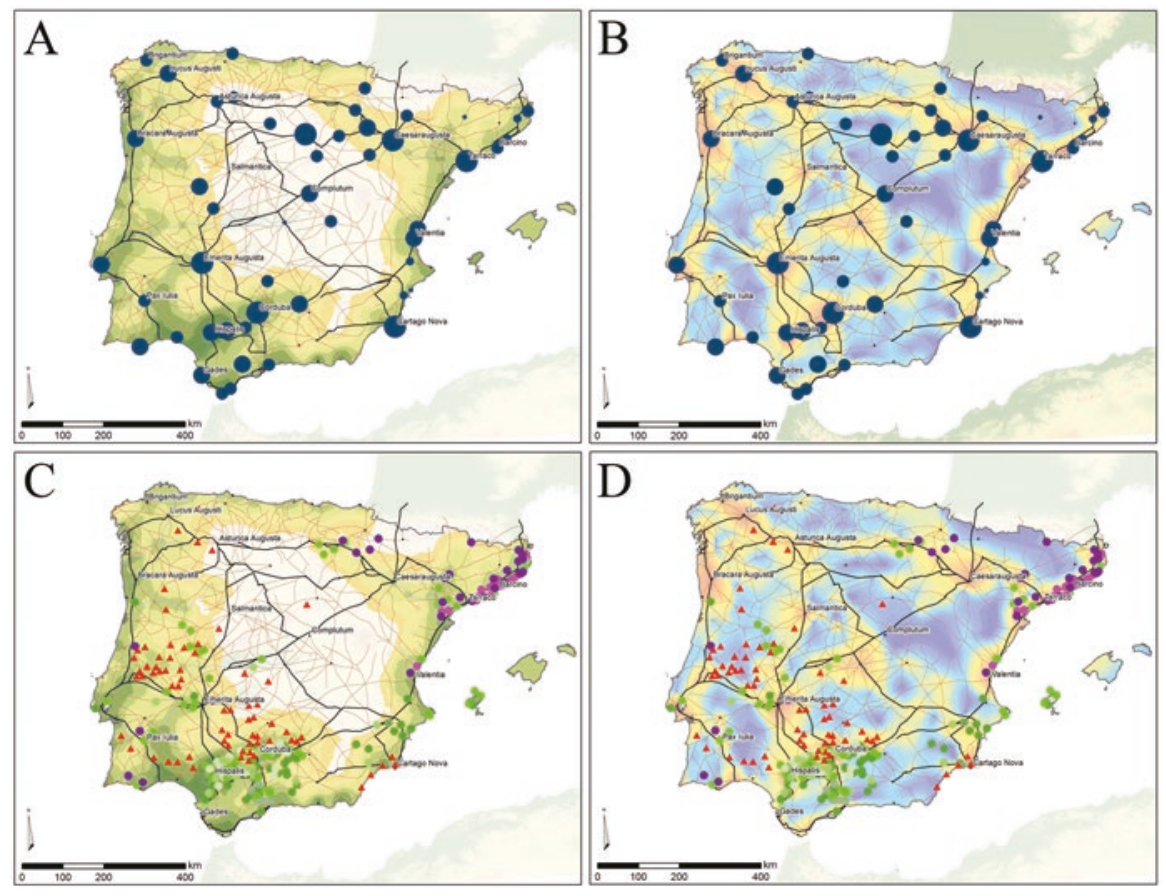

Fig. 13.5 Map with transport costs (left) and connectivity (right) in relation to the measurement of the cities (above) and the production areas (below) of oil (green), wine (purple) and mining (red) 
Acknowledgements This project has received funding from the European Union's Horizon 2020 research and innovation programme under the Marie Skłodowska-Curie grant agreement No 706260 .

\section{References}

Adams C (2007) Land transport in Roman Egypt: a study of economics and administration in a Roman province. Oxford University Press, Oxford. https://doi.org/10.1093/acprof: oso/9780199203970.001.0001

Arias G (2004) Repertorio de caminos de la Hispania Romana. Malaga

A. Barrat, M. Barthelemy, R. Pastor-Satorras, A. Vespignani, (2004) The architecture of complex weighted networks. Proceedings of the National Academy of Sciences 101 (11):3747-3752

Almeida MJ (2017) De Emerita Augusta a Olisipo por Ebora: una leitura do território a partir da rede viaria. Universidade Nova de Lisboa, Lisbon. Available at https://repositorio.ul.pt/bitstream/10451/29682/1/ulfl238842_td.pdf. Accessed on 12 May 2018

Argüelles Álvarez PA (2015) Roman exploitation and new road infrastructures in Asturia Transmontana (Asturias, Spain). In: Roselaar S (ed) Processes of cultural change and integration in the Roman world. Brill, Leiden, pp 191-200. https://doi.org/10.1163/9789004294554_012

Arnaud P (2005) Les routes de la navigation antique. Itinéraires en Méditerranée. Éditions Errance, Paris

Bowman AS, Wilson A (2009) Quantifying the Roman economy. Methods and problems. Oxford University Press, Oxford. https://doi.org/10.1093/acprof:oso/9780199562596.001.0001

Brughmans T (2010) Connecting the dots: towards archaeological network analysis. Oxf J Archaeol 29(3):277-303. https://doi.org/10.1111/j.1468-0092.2010.00349.x

Brughmans T (2013) Thinking through networks: a review of formal network methods in archaeology. J Archaeol Method Theory 20:623-662. https://doi.org/10.1007/s10816-012-9133-8

Carreras C (1994) Una reconstrucción del comercio en cerámicas: la red de transportes en Britannia. Edicions Servei del Llibre l'Estiquarot, Barcelona

Carreras C, De Soto P (2010) Historia de la movilidad en la Península Ibérica. Redes de transporte en SIG. Editorial UOC, Barcelona

Carreras C, De Soto P (2012) La red de comunicaciones romana en cataluña: actualización y metodología. ANAS 21-22:319-340

Carreras C, De Soto P (2013) The roman transport network: a precedent for the integration of the european mobility. Hist Methods: J Quant Interdiscip Hist 46(3):117-133. https://doi.org/10.1 080/01615440.2013.803403

Casson L (1974). Travel in the ancient world. London

Casson L (1985) Ships and seamanship in the ancient world. Princeton University Press, Princeton

Collar A, Coward F, Brughmans T, Mills BJ (2015) Networks in archaeology: phenomena, abstraction, representation. J Archaeol Method Theory 22(1):1-32. https://doi.org/10.1007/ s10816-014-9235-6

Colizza V, Pastor-Satorras R, Vespignani A (2007) Reaction-diffusion processes and metapopulation models in heterogeneous networks. Nature Physics 3:276-282. https://doi.org/10.1038/ nphys 560

Cooper JP (2014) The Medieval Nile: route, navigation, and landscape in Islamic Egypt. The American University in Cairo Press, Cairo

De Callataÿ F (ed) (2014) Quantifying the Greco-Roman economy and beyond. Edipuglia, Bari

De Soto P (2010a) Anàlisi de la xarxa de comunicacions i de transport a la Catalunya romana. Estudis de distribució i mobilitat. Universitat Autònoma de Barcelona, Barcelona. Available at https://www.tdx.cat/handle/10803/5560. Accessed on 12 May 2018

De Soto P (2010b) Transportation costs in NW Hispania. In: Morais R, Carreras C (eds) The Western Roman Atlantic Façade: a study of economy and trade in the Mar Exterior. From the Republic to the Principate, Archaeopress, Oxford, pp 31-46 
De Soto P (2011) SIG y Network Analysis en el estudio de las redes de comunicación de la Cataluña. In: Mayoral C, Celestino S (eds) Tecnologías de Información Geográfica y análisis arqueológico del territorio. Actas del V Simposio Internacional de Arqueología de Mérida. Anejos de Archivo Español de Arqueología LIX:651-665

De Soto P (2013) El sistema de transportes del suroeste peninsular en época romana. Análisis desde el funcionamiento de sus infraestructuras. In: Jiménez Ávila J, Bustamante Álvarez M, García Cabezas M (eds) Actas del VI Encuentro de Arqueología del Suroeste Peninsular. Ayuntamiento de Villafranca de los Barros, Mérida, pp 1551-1576. Available at https://digital. csic.es/handle/10261/138498. Accessed on 12 May 2018

De Soto P, Carreras C (2008) Anàlisi de la xarxa de transport a la Catalunya romana: alguns apunts. Revista d'Arqueologia de Ponent 16-17, pp 177-192. Available at https://www.recercat.cat/ handle/2072/257365. Accessed on 12 May 2018

De Soto P, Carreras C (2015) GIS and Network analysis applied to the study of the transport in the Roman Hispania. In: Álvarez Martínez JM, Nogales Basarrate T, Rodà I (eds) Centre and Periphery in the Ancient World. XVIIIth Inter-national Congress of Classical Archaeology. Museo Nacional de Arte Romano, Mérida, pp 733-738

Deman A (1987) "Réflexions sur la navigation fluviale dans l'antiquité romaine". T. Hackens; P. Marchetti (eds.) Histoire economique de l'antiquité. Louvain. 79-106.

Duncan-Jones RP (1974) The Economy of the Roman Empire: Quantitative Studies. Cambridge.

Fonte J, Parcero-Oubiña C, Costa-García JM (2017) A GIS-based analysis of the rationale behind Roman roads. The case of the so-called via XVII (NW Iberian Peninsula). Mediterr Archaeol Archaeometry 17(3):163-189

Freeman LC (1979) Centrality in social networks. Conceptual classification. Soc Networks 1(3):215-239. https://doi.org/10.1016/0378-8733(78)90021-7

Giacchero M (1974) Edictum Diocletiani et Collegarum de Pretiis rerum venalium. Istituto di storia antica e scienze ausiliarie dell'Universitá di Genova, Genoa

Graham S (2006) Networks, agent-based models and the Antonine itineraries: implications for Roman archaeology. J Mediterr Archaeol 19(1):45-64. https://doi.org/10.1558/ jmea.2006.19.1.45

Horden P, Purcell N (2000) The Corrupting Sea. A study of Mediterranean history. WileyBlackwell, Oxford

Isaksen L (2008) The application of network analysis to ancient transport geography: a case study of Roman Baetica. Digit Medievalist 4. https://doi.org/10.16995/dm.20

Künow J (1980) Negotiator et ventura: Händler und transport im freiem Germanien. Marburg.

Landels JG (1978) Engineering in the Roman world. Berkeley.

Lawton B (2004) Various and ingenious machines. Power generation and transport, vol 1. Brill, Leiden

Lauffer S (1971) Diokletian's Preisedikt. DeGruyter, Berlin. https://doi.org/10.1515/9783110825398

Malmberg S (2015) 'Ships are seen gliding swiftly along the sacred tiber': The river as an artery of urban movement and development. In Östenberg I, Malmberg S, Bjørnebye J (eds) The moving city: processions, passages and promenades in ancient Rome. Bloomsbury Academic, London, pp 187-201, 307-312

McGrail S (1983) Cross-channel seamanship and navigation in the late 1st millennium BC. Oxf J Archaeol 2:299-337. https://doi.org/10.1111/j.1468-0092.1983.tb00345.x

Meijer F, Van Nijf O (1992) Trade, transport and society in the ancient world: a sourcebook. Routledge, London

Mills BJ (2017) Social network analysis in archaeology. Annu Rev Anthropol 46:379-397. https:// doi.org/10.1146/annurev-anthro-102116-041423

Moreno I (2011) Vías Romanas en Castilla y León. Available at http://www.viasromanas.net/. Accessed on 12 May 2018

Parodi MJ (2001) Ríos y lagunas de Hispania como vías de comunicación. La navegación interior en la Hispania romana. Gráficas Sol, Écija

Preiser-Kapeller J, Werther L (2016) Connecting Harbours. A comparison of traffic networks across ancient and medieval Europe. In: Harbours as objects of interdisciplinary research - 
Archaeology + History + Geoscience. RGMZ Tagungen 34/Interdisziplinäre Forschungen zu Häfen von der Römischen Kaiserzeit bis zum Mittelalter 5, pp 7-39. Available at https://arxiv. org/abs/1611.09516. Accessed on 12 May 2018

Rodà I (1998) El papel de Agripa en la trama urbana de la Hispania Augustea. In: Rodríguez Colmenero A (ed) Los orígenes de la ciudad en el noroeste hispánico. Actas del Congreso Internacional (Lugo 1996). Diputación Provincial de Lugo, Lugo, pp 275-293

Roueché C (1989) Aphrodisias in late antiquity. The late Roman and byzantine inscriptions. Society for the Promotion of Roman Studies, London

Scheidel W (2013) Explaining the maritime freight charges in Diocletian's Prices Edict. J Roman Archaeol 26:464-468. https://doi.org/10.1017/S1047759413000263

Scheidel W (2014) The shape of the Roman world: modelling imperial connectivity. J Roman Archaeol 27:7-32. https://doi.org/10.1017/S1047759414001147

Tacoma LE, Lo Cascio E (2016) Writing migration. In: Lo Cascio E, Tacoma LE (eds) The impact of mobility and migration in the Roman empire: proceedings of the twelfth workshop of the international network impact of empire (Rome, June 17-19, 2015). Brill, Leiden, pp 1-24

Opsahl T, Colizza V, Panzarasa P, Ramasco JJ (2008) Prominence and Control: The Weighted Rich-Club Effect. Physical Review Letters 101, 168702. https://doi.org/10.1103/ PhysRevLett.101.168702

Open Access This chapter is licensed under the terms of the Creative Commons Attribution 4.0 International License (http://creativecommons.org/licenses/by/4.0/), which permits use, sharing, adaptation, distribution and reproduction in any medium or format, as long as you give appropriate credit to the original author(s) and the source, provide a link to the Creative Commons licence and indicate if changes were made.

The images or other third party material in this chapter are included in the chapter's Creative Commons licence, unless indicated otherwise in a credit line to the material. If material is not included in the chapter's Creative Commons licence and your intended use is not permitted by statutory regulation or exceeds the permitted use, you will need to obtain permission directly from the copyright holder.

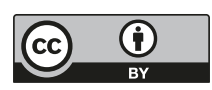

